\title{
PENGARUH EFEKTIFITAS SISTEM PERPAJAKAN, KESADARAN \\ MEMBAYAR PAJAK, DAN SANKSI PERPAJAKAN TERHADAP \\ KEMAMPUAN MEMBAYAR PAJAK WAJIB PAJAK ORANG PRIBADI DI \\ KPP PRATAMA KEBAYORAN BARU III
}

\author{
Galih Chandra Kirana, SE, M.Ak \\ Mey Nuryantii \\ chandra.galih13@gmail.com
}

Fakultas Ekonomi - Program Studi Akuntansi
Universitas Satya Negara Indonesia

\begin{abstract}
ABSTRAK
Tujuan dari penelitian ini adalah untuk melihat pengaruh efektifitas sistem perpajakan, kesadaran membayar pajak, dan sanksi perpajakan terhadap kemampuan membayar pajak wajib pajak orang pribadi di KPP Pratama Kebayoran Baru III secara parsial. Populasi dalam penelitian ini adalah wajib pajak yang terdaftar di KPP Pratama Kebayoran Baru III. Sampel dalam penelitian ini adalah wajib pajak orang pribadi. Teknik sampel yang dilakukan adalah dengan purposive sampling. Data yang digunakan adalah data premier. Alat analisis data yang digunakan adalah SPSS 22.0

Hasil penelitian menunjukan bahwa, Hasil wajib pajak orang pribadi yang diukur menggunakan tingkat efektivitas sistem perpajakan memiliki pengaruh yang positif dan signifikan terhadap kemampuan membayar pajak. Kesadaran membayar pajak dan sanksi perpajakkan yang diukur dengan menggunakan hasil yang diselesaikan wajib pajak orang pribadi tidak berpengaruh positif dan signifikan terhadap kemampuan membayar pajak.
\end{abstract}

Kata Kunci: efektifitas sistem perpajakan, kesadaran membayar pajak, sanksi perpajakan 


\section{PENDAHULUAN}

Negara Indonesia adalah negara yang sedang berkembang yang memerlukan anggaran yang cukup besar tiap tahunnya untuk melakukan pengembangan nasional.Semakin besar pengeluaran yang dikeluarkan dalam melakukan pembangunan, maka semakin besar pula penerimaan yang harus dibutuhkan oleh pemerintah.Sumber penerimaan negara dibagi menjadi 2 sumber utama yaitu sumber penerimaan negara yang berasal dari dalam negeri dan pinjaman dari luar negeri.Sumber penerimaan negara yang berasal dari dalam negeri dapat dibedakan menjadi (3) tiga yaitu penerimaan negara bukan pajak (PNBP), peneriman pajak, dan hibah.

Salah satu sumber yang berpotensi besar menambah penerimaan negara adalah penerimaan pajak.Pajak merupakan iuran wajib kepada negara berdasarkan undang undang dengan tidak mendapat balas jasa kembali secara langsung. Adanya pajak menyebabkan dua situasi: pertama, berkurangnya kemampuan individu dalam menguasai sumber daya untuk kepentingan penguasaan barang dan jasa. Kedua, bertambahnya kemampuan keuangan negara dalam penyediaan barang dan jasa publik yang merupakan kebutuhan masyarakat (Sutedi, 2011).Penerimaan ditingkatkan dengan perluasan basis pajak dan datayang akurat mengenai potensi pajak yang dapat digali secara mendalam. Semakin bertambahnya waktu, keberadaan pajak dirasa semakin penting karena digunakan sebagai pembiayaan pembangunan Negara, sehingga setiap tahun pemerintah menetapkan target kepatuhan wajib pajak semakin ditingkatkan.

Usaha meningkatkan penerimaan pajak terus dilakukan oleh pemerintah yang dalam hal ini merupakan tugas Direktorat Jenderal Pajak. Berbagai upaya dilakukan agar penerimaan pajak maksimal antara lain adalah dengan eksentifikasi dan intesifikasi pajak. Hal tersebut dilakukan dengan cara perluasan subjek dan objek pajak dengan mencari wajib pajak baru. Upaya lain dari meningkatkan penerimaan pajak yaitu reformasi sistem perpajakan secara menyeluruh. Sejak saat ini, Negara Indonesia sudah mulai menganut selfassesment system dimana para wajib pajak berhak untuk menghitung sendiriberapa jumlah iuran pajak yang harus dibayarkan sesuai dengan ketentuan Undang - Undang Perpajakan yang berlaku.

Namun dalam praktiknya, sistem pemungutan pajak di Indonesia sulit dijalankan sesuai harapan.Kepatuhan wajib pajak yang belum maksimal terlihat dari observasi awal yang dilakukan di KPP Pratama Kebayoran Baru Tiga oleh Peneliti sebelumnya menemukan bahwa pelayanan petugas pajak yang memadai tidak diikuti dengan kepatuhan wajib pajak yang maksimal.

Menurut kepala seksi humas kantor wilayah Direktorat Jendral Pajak Riau dan Kepulauan Riau, Mariyaldi, mengatakan penerimaan sector pajak dari provinsi Riau dan kepulauan Riau meningkat 20 persen jika dibandingkan dengan periode yang sama tahun sebelumnya. Hal ini ditopang oleh beberapa sector bisnis, realisasi pajak di sector migas ada kecenderungan terjadi lonjakan sehingga berimplikasi kenaikan pendapatan pajak. Tahun 2013 lalu kantor wilayah Direktorat Jendral Pajak Riau dan Kepulauan Riau, memperoleh Rp. 14,72 Triliun, atau 92 persen dari target yang ditetapkan senilai Rp.16 Triliun, sedangkan tahun ini ditargetkan sebesar Rp.18 Triliun (www.rri.co.id). 
Dengan sistem pemungutan pajak saat ini yaitu Self Assesment System.keberhasilan dari sistem ini sangat ditentukan oleh kepatuhan wajib pajak, yang mana kepatuhan membayar pajak termasuk didalamnya. Kepatuhan pajak adalah wajib pajak memenuhi kesediaan untuk memenuhi kewajiban pajaknya dengan aturan yang berlaku tanpa perlu diadakannya pemeriksaan, investigasi seksama, peringatan ataupun ancaman dan penerapan sanksi baik hukum maupun administrasi (Utami,dkk:2012).

Maka dari latar belakang diatas, penulis tertarik untuk meneliti mengenai kepuasan klien terhadap auditor dengan judul : "Pengaruh Efektifitas Sistem Perpajakan, Kesadaran Membayar Pajak, dan Sanksi Perpajakan Terhadap Kemampuan Membayar Pajak Wajib Pajak Orang Pribadi di KPP Pratama Kebayoran Baru III."

\section{Desain Penelitian}

Desain penelitian yang digunakan yaitu penelitian kausal merupakan penelitian untuk mengetahui pengaruh antara satu atau lebih variabel bebas (independent variabel) terhadap variabel terkait) (dependent variabel). Variabel bebas (independent variabel) dalam penelitian ini adalah pengaruh efektifitas sistem perpajakan $\left(X_{1}\right)$, kesadaran membayar pajak $\left(X_{2}\right)$, dan sanksi perpajakan $\left(X_{3}\right)$ dan variabel terikat dalam penelitian ini adalah kemampuan membayar pajak wajib pajak orang pribadi $(Y)$.

Adapun kerangka pemikiran penelitian dapat di gambarkan sebagai berikut :

Variabel Independen

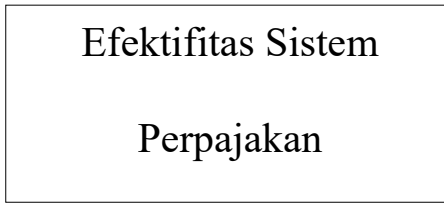

\begin{tabular}{c}
\hline Kesadaran membayar \\
pajak $\left(\mathrm{X}_{2}\right)$ \\
\hline
\end{tabular}

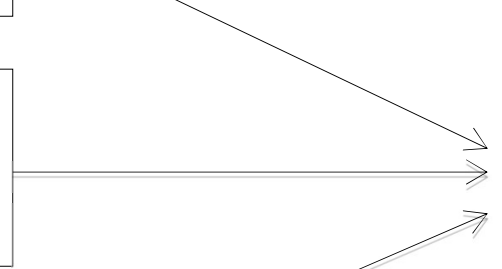

Sanksi perpajakan $\left(\mathrm{X}_{3}\right)$
Variabel Dependen

Kemampuan membayar

pajak (Y)

Gambar 3.1

Desain Penelitian 
Berdasarkan kerangka pemikiran yang telah diuraikan diatas, maka dapat diangkat hipotesis penelitian sebagai berikut:

H1: Efektifitas Sistem Perpajakan berpengaruh signifikan terhadap Kemampuan Membayar Pajak.

H2: Kesadaran Membayar Pajak berpengaruh signifikan terhadap Kemampuan Membayar Pajak.

H3: Sanksi Perpajakan berpengaruh signifikan terhadap Kemampuan Membayar Pajak.

\section{LANDASAN TEORI}

\section{Teori Perpajakan}

Istilah pajak bukan lagi merupakan sesuatu yang asing dan sering menjadi bahan diskusi para ahli dan ekonomi, karena pajak merupakan hal yang tidak dapat dihindari sebagai seorang warga Negara. Menurut Mardiasmo (2016:1) pajak adalah "Iuran rakyat pada Negara berdasarkan Undang-Undang (yang dapat dipaksakan) dengan tidak dapat mendapat jasa timbal (kontra Prestasi) yang langsung dapat ditunjukan dan yang digunakan untuk membayar pengeluaran umum."

Pengertian Pajak menurut Undang-Undang Nomor 6 Tahun 1983 Tentang Ketentuan Umum dan Tata Cara Perpajakan Sebagaimana Telah Beberapa Kali Diubah Terakhir dengan Undang-Undang No. 28 Tahun 2007 Pasal 1, yaitu: "Pajak adalah kontribusi wajib kepada negara yang terutang oleh orang pribadi atau badan yang bersifat memaksa berdasarkan Undang-Undang, dengan tidak mendapatkan imbalan secara langsung dan digunakan untuk keperluan negara bagi sebesar-besarnya kemakmuran rakyat."

\section{Efektifitas Sistem Perpajakan}

Seiring dengan meningkatnya kesadaran masyarakat akan membayar pajak, maka diperlukan perubahan atau penyempurnaan dan perbaikan dalam sistem administrasi modern berdasarkan Peraturan Menteri Keuangan Nomor 68/PMK.01/2011 tentang Organisasi dan Tata Kerja Intansi Vertikal Direktorat Jendral Pajak mengenai tentang pedoman Umum Kelembagaan Instansi yang menerapkan pola pengelolaan keuangan badan layanan umum. Dari sisi akuntabilitas, berdasarkan hasil evaluasi akuntabilitas kinerja instansi pemerintah pusat tahun 2011 .

Berdasarkan hal tersebut diharapkan sistem perpajakan yang sekarang sudah ada seperti e-SPT, e-filling, e-NPWP, e-registration, e-banking dan drop box, dan lainnya dapat lebih sempurna serta memberikan kemudahan kepada wajib pajak dalam membayr atau melaporkan kewajiban perpajakan dan dapat memberikan pencitraan atau persepsi yang baik kepada hal yang terkait dengan pajak terutama pada sistem perpajakan. Menurut Fikriningrum dan Syafruddin (2012:4) hal-hal yang mengindikasikan efektifitas sistem perpjakan yang saat ini dapat dirasakan oleh wajib antara lain : 1. Adanya sistem pelaporan melalui e-SPT dan e-Filling. Wajib pajak dapat melaporkan pajak secara lebih mudah dan cepat. 2. Pembayaran melalui e-banking yang memudahkan wajib pajak dapat melakukan pembayaran dimana saja dan kapan saja. 3. penyampaian SPT melalui drop box yang dapat dilakukan diberbagai tempat, 
tidak harus di KPP tempat wajib pajak terdaftar. 4.peraturan perpajakan dapat diakses secara lebih cepat melalui internet, tanpa harus menunggu adanya pemberitahuan dari KPP tempat wajib pajak tersebut. 5.pendaftaran NPWP yang dapat dilakukan secara online melalui e-registration dan website pajak. Hal ini akan memudahkan wajib oajak untuk memperoleh NPWP secara lebih cepat. Persepsi wajib pajak terhadap sistem perpajakan di Indonesia berkaitan dengan media yang digunakan dalam membayar pajak. Jika wajib pajak merasa bahwa sistem perpajakan yang ada adalah terpercaya, handal dan akurat, maka wajib pajak akan memiliki pandangan yang positif untuk sadar membayar pajak. Namun jika sistem perpajakan yang ada tidak memuaskan bagi wajib pajak, maka hal itu dapat turut mempengaruhi kesadaran wajib pajak.

\section{Kesadaran Membayar Pajak}

Kesadaran merupakan unsur dalam manusia yang dapat memahami realitas dan bagaimana cara bertindak atau menyikapi realitas. Vanesa dan Hari (2009:14) menyatakan bahwa : "Kemauan membayar pajak merupakan suatu nilai yang rela dikontribusikan oleh seseorang (yang ditetapkan dengan peraturan) yang digunakan untuk membiayai pengeluaran umum negara dengan tidak mendapatkan jasa timbal (kontraprestasi) secara langsung”. Irianto (2010:41) menguraikan beberapa bentuk kesadaran membayar pajak yang mendorong wajib pajak untuk membayar pajak, yaitu:

a. Kesadaran bahwa pajak merupakan bentuk partisipasi dalam menunjang pembangunan negara. Kesadaran ini akan membuat wajib pajak mau membayar pajak karena merasa tidak dirugikan dari pemungutan pajak yang dilakukan. Pajak disadari digunakan untuk pembangunan negara guna meningkatkan kesejahteraan masyarakat.

b. Kesadaran bahwa penundaan pembayaran pajak dan pengurangan beban pajak sangat merugikan negara. Wajib pajak mau membayar pajak karena memahami bahwa penundaan pembayaran pajak dan pengurangan beban pajak berdampak pada kurangnya sumber daya finansial yang dapat mengakibatkan terhambatnya pembangunan.

c. Kesadaran bahwa pajak ditetapkan dengan undang-undang dan dapat dipaksakan. Wajib pajak akan membayar pajak karna menyadari adanya landasan hukum yang kuat dan merupakan kewajiban mutlak setiap warga negara.

\section{Sanksi Perpajakan}

Menurut Aristanti Widyaningsih (2013:312) dalam buku Hukum Pajak dan Perpajakan, Sanksi Perpajakan adalah "Sanksi berupa administrasi dan pidana yang dikenakan terhadap setiap orang yang melakukan pelanggaran perpajakan yang secara nyata telah diatur dalam Undang-undang." Sedangkan Mardiasmo (2009:57) dalam buku Perpajakan menyatakan Sanksi perpajakan adalah "Jaminan bahwa ketentuan peraturan perundang-undangan perpajakan (norma perpajakan) akan dituruti/ditaati/dipatuhi. Atau dengan kata lain sanksi perpajakan merupakan alat pencegah (preventif) agar Wajib Pajak tidak melanggar norma perpajakan.”

\section{Kemampuan Membayar Pajak}

Jurnal Ilmiah Akuntansi dan Ekonomi Volume. 1 Nomor. 5 Februari 2020

Hal. 69 
Dalam kamus lengkap Bahasa Indonesia mendefinisikan kemampuan sebagai dorongan dari dalam diri yang sadar, berdasarkan pertimbangan pikir dan perasaan, serta seluruh pribadi seseorang yang menimbulkan kegiatan yang terarah pada tercapainya tujuan tertentu yang berhubungan dengan kebutuhan hidupnya. Dalam konsep kemampuan membayar pajak menurut handayani , dkk (2012) dikembangkan pula melalui dua subkonsep yaitu, konsep kemampuan membayar dan konsep pajak.

Kemampuan membayar merupakan suatu nilai dimana seseorang rela untuk membayar, mengorbankan atau menukarkan sesuatu untuk memperoleh barang atau jasa. Sedangkan yang kedua adalah konsep pajak, pajak adalah prestasi yang dipaksakan sepihak oleh dan terutang kepada pengusaha (menurut norma-norma yang ditetapkan secara umum), tanpa adamya kontraprestasi, dan semata - mata digunakan untuk menutup pengeluaran- pengeluaran umum.

\section{METODOLOGI PENELITIAN}

Metode penelitian menyangkut prosedur dan cara melakukan pengolahan data yang diperlukan untuk menjawab atau memecahkan masalah penelitian termasuk menguji hipotesis. Untuk mengungkap permasalahan dalam penelitian ini, maka peneliti menggunakan metode kausal. Metode kausal merupakan metode yang digunakan untuk mengetahui hubungan antara dua variabel atau lebih.Bentuk metode yang digunakan dalam penelitian ini adalah bentuk kausal (hubungan sebab akibat).

Tabel

Operasional Variabel

\begin{tabular}{|c|c|c|c|}
\hline No. & Variabel & Indikator & Skala Data \\
\hline 1 & $\begin{array}{l}\text { Efektifitas sistem } \\
\text { Perpajakan } \\
\left(\mathrm{X}_{1}\right) \\
(\text { Widayati } 2010: 25)\end{array}$ & $\begin{array}{l}\text { a. pembayaran pajak melalui e- } \\
\text { Banking } \\
\text { b. Penyampaian SPT melalui e- } \\
\text { SPT dan e-Felling } \\
\text { c. Penyampaian SPT melalui drop } \\
\text { box } \\
\text { d. Update peraturan pajak terbaru } \\
\text { secara online melalui internet }\end{array}$ & Ordinal \\
\hline
\end{tabular}

Jurnal Ilmiah Akuntansi dan Ekonomi Volume. 1 Nomor. 5 Februari 2020

Hal. 70 


\begin{tabular}{|c|c|c|c|}
\hline & & $\begin{array}{l}\text { e. Pendaftaran NPWP melalui e- } \\
\text { Register }\end{array}$ & \\
\hline 2 & $\begin{array}{l}\text { Kesadaran membayar } \\
\text { pajak } \\
\left(\mathrm{X}_{2}\right) \\
(\text { Widayati } 2010: 32)\end{array}$ & $\begin{array}{l}\text { a. Pajak merupakan bentuk } \\
\text { partisipasi dalam menunjang } \\
\text { pembangunan negara } \\
\text { b. Penundaan pembayaran pajak } \\
\text { dan pengurasngan beban pajak } \\
\text { sangat merugikan Negara } \\
\text { c.Pajak di tetapkan dengan } \\
\text { undang-undang dan dapat } \\
\text { dipaksakan tidak sesuai } \\
\text { d.Membayar pajak tibayar } \\
\text { dengan yang seharusnya dibara } \\
\text { akan merugikan Negara }\end{array}$ & Ordinal \\
\hline 3 & $\begin{array}{l}\text { Sanksi Perpajakan } \\
\left(X_{3}\right) \\
(\text { Prof.Dr.mardiasmo. } 201 \\
6: 4)\end{array}$ & $\begin{array}{l}\text { a. Sanksi bunga } \\
\text { b. Sanksi denda } \\
\text { c. Kenaikan } \\
\text { d. Sanksi pidana kurungan } \\
\text { e. Sanksi pidana penjara }\end{array}$ & Ordinal \\
\hline 4 & $\begin{array}{l}\text { Kemampuan membayar } \\
\text { pajak } \\
(Y) \\
(\text { Vanessa } 2009: 15)\end{array}$ & $\begin{array}{lll}\text { a. } & \text { Konsultasi } \\
& \text { pembayaran pajak } \\
\text { b. } & \text { Dokumen yang diperlukan } \\
& \text { dalam membayar pajak }\end{array}$ & Ordinal \\
\hline
\end{tabular}




\begin{tabular}{|c|c|c|}
\hline & dede & $\begin{array}{l}\text { c. Membayar pajak sesuai dengan } \\
\text { peraturan perpajakan yang } \\
\text { berlaku } \\
\text { d. Mendaftarkan sendiri sebagai } \\
\text { wajib pajak untuk } \\
\text { mendapatkan NPWP } \\
\text { e. Membuat alokasi dana untuk } \\
\text { membayar pajak }\end{array}$ \\
\hline
\end{tabular}

Sumber : data diolah 2019

\section{Populasi dan Teknik Penarikan Sampel}

Populasi dalam penelitian ini adalah wajib pajak orang pribadi yang terdaftar di KPP Pratama Kebayoran Baru III Jakarta Selatan.

Penentuan KPP yang dijadikan sampel dalam penelitian ini yaitu dengan konfirmasi kesediaan KPP untuk berpartisipasi dalam pengisian kuesioner, hal ini terkait dengan kesibukan KPP.Sampel dengan penelitian ini diambil menggunakan metode Purposive Samplingyaitu merupakan tehnik pengambilan sampel yang didasarkan atas pertimbangan - pertimbangan tertentu dari peneliti.Pemberian kriteria ini bertujuan agar pernyataan yang terdapat dalam kuesioner penelitian di isi oleh responden yang tepat. Kriteria respoden ini nantinya akan dikelompokkan sebagai komponen karakteristik responden dalam kuesioner. Kriteria responden dari KPP yang dijadikan sampel dalam penelitian ini adalah sebagai berikut :

a. Memiliki NPWP Jakarta Selatan.

b. Wajib pajak orang pribadi usia $>20$ tahun sampai $<60$ tahun.

c. Wajib pajak tersebut berada di ruang lingkup KPP Kebayoran Baru Tiga.

\section{HASIL PENELITIAN}

Jumlah kuesioner yang dikirim dan kuesioner yang tidak sesuai dengan kriteria untuk masing-masing di KPP Pratama Kebayoran Baru III dapat dilihat pada tabel berikut :

Tabel

Tabel Penyebaran Kuisioner

\begin{tabular}{|c|c|c|c|}
\hline No. & Keterangan & Jumlah & Presentasi \\
\hline 1 & Jumlah kuisioner yang disebar & 130 & $100 \%$ \\
\hline
\end{tabular}

Jurnal Ilmiah Akuntansi dan Ekonomi Volume. 1 Nomor. 5 Februari 2020

Hal. 72 


\begin{tabular}{|c|c|c|c|}
\hline 2 & $\begin{array}{c}\text { Jumlah kuisioner yang tidak sesuai } \\
\text { dengan criteria }\end{array}$ & 30 & $23,1 \%$ \\
\hline 3 & Jumlah Kuisioner yang dapat diolah & 100 & $76,9 \%$ \\
\hline
\end{tabular}

Sumber: KPP Kebayoran Baru 3, data diolah 2020

\section{Uji Reliabilitas}

Nilai Cronbach's Alpha yang biasanya digunakan yaitu: lebih besar dari 0,7 atau > 0,7. Semakin besar nilai Cronbach's Alpha, maka semakin baik pula pengukuran variabel tersebut.

Tabel

Uji Reliabilitas

\begin{tabular}{|c|c|c|c|c|}
\hline No. & Variabel & $\begin{array}{c}\text { Cronbach's } \\
\text { Alpha }\end{array}$ & Item Indikator & Kesimpulan \\
\hline 1 & $\begin{array}{c}\text { Efektifitas } \\
\text { Sistem } \\
\text { perpajakan }\end{array}$ & 0,790 & 5 & Reliabel \\
\hline 2 & $\begin{array}{c}\text { Kesaran } \\
\text { Membayar } \\
\text { Pajak }\end{array}$ & 0,824 & 4 & Reliabel \\
\hline 3 & $\begin{array}{c}\text { Sanksi } \\
\text { Perpajakan }\end{array}$ & 0,799 & 4 & Reliabel \\
\hline 4 & $\begin{array}{c}\text { Kemampuan } \\
\text { Membayar } \\
\text { Pajak }\end{array}$ & 0,837 & 5 & Reliabel \\
\hline
\end{tabular}

Sumber : Output Spss Versi 22

Berdasarkan hasil uji reliabilitas di atas dapat disimpulkan bahwa pernyataan dalam kuisioner ini reliable karena mempunyai nilai Cronbach's Alpha lebih besar dari 0,7 artinya Efektifitas Sistem Perpajakan, Kesadaran Membayar Pajak, Sanksi Perpajakan, dan Kemampuan Membayar Pajak bersifat reliabel atau dapat dipercaya.

\section{Uji Normalitas}

Hasil uji normalitas dengan menggunakan Uji Kolmogorof Smirnov adalah sebagai berikut :

\section{Tabel}

\section{Uji Normalitas}


One-Sample Kolmogorov-Smirnov Test

\begin{tabular}{|ll|r|}
\hline & & $\begin{array}{c}\text { Unstandardized } \\
\text { Residual }\end{array}$ \\
\hline Normal Parameters ${ }^{\mathrm{a}, \mathrm{b}}$ & Mean & 100 \\
& Std. Deviation &, 0000000 \\
Most Extreme Differences & Absolute & 2,66639800 \\
& Positive &, 048 \\
& Negative &, 048 \\
Test Statistic & &,- 038 \\
Asymp. Sig. (2-tailed) & &, 048 \\
\hline
\end{tabular}

a. Test distribution is Normal.

b. Calculated from data.

Berdasarkan hasil uji normalitas dengan One Sample Kolmogorov dapat diketahui bahwa data dalam penelitian terdistribusi normal. Hal ini dapat dilihat dari Asymp Sig (2-tailed) nilai Sig $=0,200>\alpha=0,05$ berarti dapat disimpulkan bahwa data tersebut berdistribusi normal dan populasi berdistribusi normal.

\section{Uji Multikolinieritas}

Uji Multikoliniearitas bertujuan untuk menguji apakah model regresi ditemukan adanya korelasi antar variabel bebas (independent).

\section{Tabel}

\section{Uji Multikoliniearitas}

\begin{tabular}{|c|c|c|c|}
\hline \multirow[b]{2}{*}{ Mode } & & \multicolumn{2}{|c|}{ Collinearity Statistics } \\
\hline & & Tolerance & VIF \\
\hline \multirow{4}{*}{1} & (Constant) & & \\
\hline & $\begin{array}{l}\text { EFEKTIFITAS SISTEM } \\
\text { PERPAJAKAN }\end{array}$ & ,590 & 1,693 \\
\hline & $\begin{array}{l}\text { KESADASARAN } \\
\text { MEMBAYAR PAJAK }\end{array}$ & ,471 & 2,123 \\
\hline & SANKSI PERPAJAKAN & ,457 & 2,189 \\
\hline
\end{tabular}


Berdasarkan hasil tabel di atas, dapat dilihat bahwa masing- masing variable independen yang digunakan dalam penelitian memiliki nilai VIF $<10$ dan Tolerance $>$ 0,10. Yaitu dengan nilai dari variable Efektifitas sistem perpajakan mempunyai VIF 1,693 dan Tolerance 0,590, nilai variabel Kesadaran membayar pajak mempunyai VIF 2,123 dan Tolerance 0,471, dan nilai dari variabel Sanksi perpajakan mempunyai VIF 2,189 dan Tolerance 0,457, Hal ini menandakan bahwa variabel-variabel yang digunakan tidak terjadi masalah multikolinearitas.

\section{Uji Heterokedastisitas}

Untuk menguji hal ini digunakan Scatterplot, dimana sumbu X adalah nilainilai prediksi, Selain itu uji heterokedastisitas dilakukan dengan uji glejser, dengan melihat nilai Sig lebih besar dari 0,05 maka tidak terjadi heterokedastisitas, maka berikut hasil ujinya :

\section{Tabel}

\section{Uji Heterokedastisitas}

\begin{tabular}{|ll|r|r|}
\hline & & & \multicolumn{1}{|c|}{} \\
\hline Model & & \multicolumn{1}{c|}{$\mathrm{T}$} & \multicolumn{1}{c|}{ Sig. } \\
\hline 1 & (Constant) & 3,982 &, 000 \\
& Otonomi & $-1,317$ &, 191 \\
& Ambiguitas Peran & $-1,843$ &, 069 \\
& Profesionalisme &, 499 &, 619 \\
\hline
\end{tabular}

a. Dependent Variable: Abs_RES

Sumber : Output Spss Versi 22

Dari output di atas dapat dapat diketahui bahwa nilai sig variabel Efektifitas Sistem Perpajakan, Kesadaran Membayar Pajak, dan Sanksi Perpajakan diatas 0,05, Jadi dapat disimpulkan bahwa tidak terjadi heterokedastisitas dalam model regresi atau uji glejser

\section{Uji Auto Korelasi}

Uji autokorelasi bertujuan menguji apakah dalam model regresi linear ada korelasi antara kesalahan pengganggu pada periode $t$ dengan kesalahan pengganggu pada periode t-1 (sebelumnya). Model regresi yang baik adalah regresi yang bebas dari autokorelasi. Metode pengujian yang sering digunakan adalah dengan uji DurbinWatson (Uji DW). 


\section{Tabel}

\section{Uji Auto Korelasi}

\begin{tabular}{l|r|r|r|r|r|}
\hline Model & $\mathrm{R}$ & $\mathrm{R}$ Square & $\begin{array}{c}\text { Adjusted R } \\
\text { Square }\end{array}$ & $\begin{array}{c}\text { Std. Error of the } \\
\text { Estimate }\end{array}$ & $\begin{array}{c}\text { Durbin- } \\
\text { Watson }\end{array}$ \\
\hline 1 &, $682^{\mathrm{a}}$ &, 466 &, 449 & 2,70774 & 1,989 \\
\hline a. $\begin{array}{l}\text { Predictors: (Constant), SANKSI PERPAJAKAN, EFEKTIFITAS SITEM PERPAJAKAN, } \\
\text { KESADARAN MEMBAYAR PAJAK }\end{array}$ \\
b. Dependent Variable: KEMAMPUAN MEMBAYAR PAJAK
\end{tabular}

Sumber : Output Spss Versi 22

Berdasarkan hasil tabel diatas dengan uji Durbin Watson menunjukkan nilai sebesar 1,989 yang artinya bahwa $\mathrm{dU}<\mathrm{d}<4$-dU maka diindikasikan tidak ada autokorelasi.

\section{Analisis Korelasi}

Untuk menganalisis korelasi antara variable Efektifitas Sistem Perpajakan, Kesadaran Membayar Pajak, dan Sanksi Perpajakan Terhadap Kemampuan Membayar Pajak.

\section{Tabel}

\section{Uji Analisis Korelasi}

Correlations

\begin{tabular}{|c|c|c|c|c|c|}
\hline & & $\begin{array}{c}\text { EFEKTIFITAS } \\
\text { SITEM } \\
\text { PERPAJAKAN }\end{array}$ & $\begin{array}{l}\text { KEMAMPUAN } \\
\text { MEMBAYAR } \\
\text { PAJAK }\end{array}$ & $\begin{array}{l}\text { KESADARAN } \\
\text { MEMBAYAR } \\
\text { PAJAK }\end{array}$ & $\begin{array}{c}\text { SANKSI } \\
\text { PERPAJAKA } \\
\mathrm{N}\end{array}$ \\
\hline \multirow{3}{*}{$\begin{array}{l}\text { EFEKTIFITAS } \\
\text { SITEM } \\
\text { PERPAJAKAN }\end{array}$} & Pearson Correlation & 1 &, $651^{* *}$ &, $581^{* *}$ &, $598^{* *}$ \\
\hline & Sig. (2-tailed) & &, 000 &, 000 &, 000 \\
\hline & $\mathrm{N}$ & 100 & 100 & 100 & 100 \\
\hline \multirow{3}{*}{$\begin{array}{l}\text { KEMAMPUAN } \\
\text { MEMBAYAR } \\
\text { PAJAK }\end{array}$} & Pearson Correlation & ,651 & 1 &, $536^{\star *}$ &, $520^{\star \star}$ \\
\hline & Sig. (2-tailed) &, 000 & &, 000 &, 000 \\
\hline & $\mathrm{N}$ & 100 & 100 & 100 & 100 \\
\hline \multirow{3}{*}{$\begin{array}{l}\text { KESADARAN } \\
\text { MEMBAYAR } \\
\text { PAJAK }\end{array}$} & Pearson Correlation &, $581^{* \star}$ &, $536^{* *}$ & 1 &, $698^{* *}$ \\
\hline & Sig. (2-tailed) &, 000 &, 000 & &, 000 \\
\hline & $\mathrm{N}$ & 100 & 100 & 100 & 100 \\
\hline \multirow{3}{*}{$\begin{array}{l}\text { SANKSI } \\
\text { PERPAJAKAN }\end{array}$} & Pearson Correlation &, $598^{* *}$ &, $520^{* \star}$ & $698^{* *}$ & 1 \\
\hline & Sig. (2-tailed) &, 000 &, 000 &, 000 & \\
\hline & $\mathrm{N}$ & 100 & 100 & 100 & 100 \\
\hline
\end{tabular}

${ }^{* *}$. Correlation is significant at the 0.01 level (2-tailed).

Sumber: Output Spss Versi 22

Agar mempermudah interprestasi, data di atas disajikan dalam bentuk model path analysis sebagai berikut : 


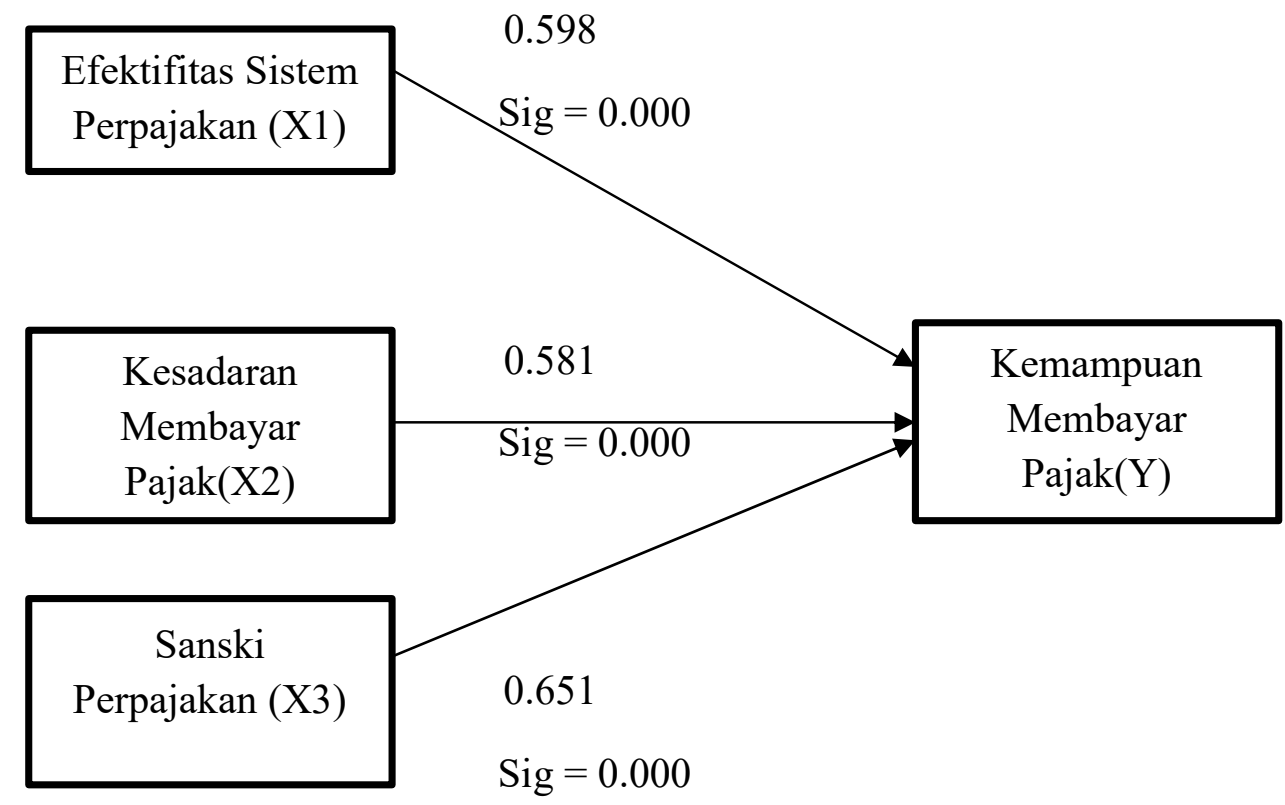

\section{Gambar}

\section{Path Analysis Korelasi}

Berdasarkan gambar 4.1 path analysis diatas, selanjutnya dapat dilakukan interprestasi hubungan masing-masing variabel sebagai berikut :

a. Hubungan Efektifitas Sistem Perpajakan (X1) terhadap Kemampuan Membayar Pajak (Y)

Hubungan Efektifitas sistem perpajakan terhadap kemampuan membayar pajak diperoleh hasil sebesar 0.598 dengan signifikan sebesar $0.000<0.05$. Angka ini menunjukkan Efektifitas sistem perpajakan memiliki korelasi yang cukup kuat yaitu sebesar 59,80\% terhadap kemampuan membayar pajak.

b. Hubungan Kesadaran Membayar Pajak (X2) terhadap Kemampuan Membayar Pajak (Y)

Hubungan Kesadaran membayar pajak terhadap kemampuan membayar pajak sebesar 0.581 dengan signifikan sebesar $0.000<0.05$. Angka ini menunjukkan kesadaran membayar pajak memiliki korelasi yang cukup kuat yaitu sebesar $58.10 \%$ terhadap kemampuan membayar pajak.

c. Hubungan Sanksi Perpajakan (X3) terhadap Kemampuan Membayar Pajak (Y)

Hubungan Sanksi Perpajakan terhadap kemampuan membayar pajak sebesar 0.651 dengan signifikan sebesar $0.000<0.05$. Angka ini menunjukkan memiliki korelasi yang cukup kuat yaitu sebesar $65.10 \%$ terhadap kemampuan membayar pajak. 


\section{Analisis Regresi Linier Berganda}

Dalam Pengolahan data dengan menggunakan metode regresi linear berganda, dilakukan beberapa tahapan untuk mencari hubungan variable independen dan variable dependen, yaitu dengan cara menganalisis Efektifitas Sistem Perpajakan (X1), Kesadaran Membayar Pajak (X2), dan Sanksi Perpajakan (X3), terhadap Kemampuan Membayar Pajak (Y).

\section{Tabel}

\section{Uji Analisis Regresi Linier Berganda}

\begin{tabular}{|c|c|c|c|c|c|c|}
\hline \multirow[b]{2}{*}{ Mod } & & \multicolumn{2}{|c|}{$\begin{array}{l}\text { Unstandardized } \\
\text { Coefficients }\end{array}$} & \multirow{2}{*}{$\begin{array}{c}\begin{array}{c}\text { Standardized } \\
\text { Coefficients }\end{array} \\
\text { Beta }\end{array}$} & \multirow[b]{2}{*}{$\mathrm{t}$} & \multirow[b]{2}{*}{ Sig. } \\
\hline & & B & Std. Error & & & \\
\hline \multirow[t]{4}{*}{1} & (Constant) & 4,196 & 1,397 & & 3,004 & ,003 \\
\hline & $\begin{array}{l}\text { EFEKTIFITAS SITEM } \\
\text { PERPAJAKAN }\end{array}$ & ,509 & 103 & 482 & 4,966 & ,000 \\
\hline & $\begin{array}{l}\text { KESADARAN MEMBAYAR } \\
\text { PAJAK }\end{array}$ & 218 & 130 & 182 & 1,676 & 097, \\
\hline & SANKSI PERPAJAKAN & 128 & 136 & 105 & 947 & 346 \\
\hline
\end{tabular}

a. Dependent Variable: KEMAMPUAN MEMBAYAR PAJAK

Sumber : Output Spss Versi 22

Berdasarkan tabel 4.18 maka diperoleh bentuk persamaan model regresi linear berganda sebagai berikut:

$$
\begin{aligned}
& Y=\alpha+\beta_{1} X_{1}+\beta_{2} X_{2}+\beta_{3} X_{3}+€ \\
& Y=\mathbf{4 , 1 9 6}+\mathbf{0 , 5 0 9} \mathbf{X}_{\mathbf{1}}+\mathbf{0 , 2 1 8} \mathbf{X}_{\mathbf{2}}+\mathbf{0 , 1 2 8} \mathbf{X}_{\mathbf{3}}
\end{aligned}
$$

Model tersebut dapat di interpretasikan sebagai berikut :

1. Nilai a (konstanta) pada hasil pengujian di atas adalah sebesar 4,196 yang berarti bahwa jika variabel independen (Efektifitas Sistem Perpajakan, Kedasaran Membayar Pajak dan Sanksi Perpajakan) konstan, maka Kemampuan Membayar Pajak akan mengalami kenaikan sebesar 4,196. Nilai konstanta sebesar 4,196 menunujukkan nilai murni dari variabel Kemampuan Membayar Pajak (dependen) tanpa di pengaruhi variabel independen.

2. Koefisien Efektifitas Sistem Perpajakan adalah sebesar 0,509 dimana angka ini menunjukkan bahwa setiap peningkatan variabel Efektifitas Sistem Perpajakan sebesar satu satuan, maka akan meningkatkan Kemampuan Membayar Pajak sebesar 0,509. Koefisien bernilai positif artinya terdapat hubungan positif antara Efektifitas Sistem Perpajakan. Semakin meningkat Efektifitas Sistem Perpajakan maka akan meningkatkan Kemampuan Membayar Pajak.

3. Koefisien Kesadaran Membayar Pajak adalah sebesar 0,218 dimana angka ini menunjukkan bahwa setiap penurunan variabel Kesadaran Membayar Pajak sebesar satu satuan, maka akan meningkatkan Kemampuan Membayar Pajak 
sebesar 0,218. Koefisien bernilai positif artinya terdapat hubungan positif Kesadaran Membayar Pajak. Semakin meningkatkan Kesadaran Membayar Pajak, maka akan meningkatkan Kemampuan Membayar pajak.

4. Koefisien Sanksi Perpajakan adalah sebesar 0,128 dimana angka ini menunjukkan bahwa setiap peningkatan variabel Sanksi perpajakan sebesar satu satuan, maka akan meningkatkan Kesadaran Membayar Pajak sebesar 0,128. Koefisien bernilai positif artinya terdapat hubungan positif antara Sanksi Perpajakan. Semakin meningkat Sanski Perpajakan, maka akan meningkatkan Kesadaran Membayar Pajak

\section{Uji Parsial ( Uji t )}

Uji t digunakan untuk mengetahui apakah dalam model regresi variabel bebas (independent variable) secara parsial (individual) berpengaruh terhadap variabel terikat (dependen variable).

Tabel

Hasil Uji Signifikansi Parsial (Uji t)

\begin{tabular}{|c|c|c|c|c|c|c|}
\hline \multirow{2}{*}{\multicolumn{2}{|c|}{ Model }} & \multicolumn{2}{|c|}{$\begin{array}{l}\text { Unstandardized } \\
\text { Coefficients }\end{array}$} & \multirow{2}{*}{$\begin{array}{c}\begin{array}{c}\text { Standardized } \\
\text { Coefficients }\end{array} \\
\text { Beta }\end{array}$} & \multirow[b]{2}{*}{$\mathrm{t}$} & \multirow[b]{2}{*}{ Sig. } \\
\hline & & $\mathrm{B}$ & Std. Error & & & \\
\hline \multirow[t]{4}{*}{1} & (Constant) & 4,196 & 1,397 & & 3,004 &, 003 \\
\hline & $\begin{array}{l}\text { EFEKTIFITAS SITEM } \\
\text { PERPAJAKAN }\end{array}$ &, 509 & ,103 & ,482 & 4,966 &, 000 \\
\hline & $\begin{array}{l}\text { KESADARAN MEMBAYAR } \\
\text { PAJAK }\end{array}$ & ,218 & ,130 & ,182 & 1,676 & ,097 \\
\hline & SANKSI PERPAJAKAN & ,128 & ,136 & ,105 & ,947 & ,346 \\
\hline
\end{tabular}

a. Dependent Variable: KEMAMPUAN MEMBAYAR PAJAK

Sumber : Output Spss Versi 22

a) Hipotesis yang pertama adalah Efektifitas Sistem Perpajakan, dimana variabel ini untuk melihat pengaruh antara variabel independen (Efektifitas Sistem Perpajakan) dengan variabel dependen (Kesadaran Membayar Pajak), dengan hipotesis $\left(H_{0}\right)$ dan hipotesa alternatif $\left(H_{1}\right)$ sebagai berikut :

$H_{0}$ : Efektifitas Sistem Perpajakan tidak berpengaruh terhadap Kesadaran Membayar Pajak.

$H_{1}$ : Efektifitas Sistem Perpajakan berpengaruh terhadap Kesadaran Membayar Pajak.

Berdasarkan tabel 4.17 diatas terlihat bahwa $t_{\text {hitu }}<t_{\text {tabel }}$ yaitu 4,966 > 1,984 sedangkan nilai signifikan yang dihasilkan lebih kecil dari alpha $(\alpha)$, yakni $0,000<0,05$. Hal ini berarti menunjukkan bahwa keputusan yang diambil adalah menolak H0 dan menerima $\mathrm{H}$ 1, berarti secara parsial Efektifitas Sistem Perpajakan berpengaruh secara signifikan terhadap Kemampuan Membsayar Pajak. 
b) Hipotesis yang kedua adalah Kesadaran Membayar Pajak, dimana variabel ini untuk melihat pengaruh antara variabel independen (Kesadaran Membayar Pajak) dengan variabel dependen (Kemampuan Membayar Pajak), dengan hipotesis $\left(H_{0}\right)$ dan hipotesa alternatif $\left(H_{1}\right)$ sebagai berikut :

$H_{0}$ : Kesadaran Membayar Pajak tidak berpengaruh terhadap Kemampuan Membayar Pajak.

$H_{1}$ : Kesadaran Membayar Pajak berpengaruh terhadap

Kemampuan Membayar Pajak.

Berdasarkan tabel 4.17 diatas terlihat bahwa $t_{\text {hitung }}>t_{\text {tabel }}$ yaitu $1,676<1,984$ sedangkan nilai signifikan yang dihasilkan lebih besar dari alpha $(\alpha)$, yakni $0,097>0.05$. Hal ini berarti menunjukkan bahwa keputusan yang diambil adalah menerima H0 dan menolak H1, berarti secara parsial Kesadaran Membayar Pajak tidak berpengaruh terhadap Kemampuan Membayar Pajak.

c) Hipotesis yang ketiga adalah Sanksi Perpajakan, dimana variabel ini untuk melihat pengaruh antara variabel independen (Sanksi Perpajakan) dengan variabel dependen (Kemampuan Membayar Pajak), dengan hipotesis $\left(H_{0}\right)$ dan hipotesa alternatif $\left(H_{1}\right)$ sebagai berikut:

$H_{0}$ : Sanksi Perpajakan tidak berpengaruh terhadap Kemampuan Membayar Pajak.

$H_{1}$ : Sanksi Perpajakan berpengaruh terhadap Kemampuan Membayar Pajak.

Berdasarkan tabel 4.17 diatas terlihat bahwa $t_{\text {hitun }}>t_{\text {tabel }}$ yaitu $0,947<1,984$ sedangkan nilai signifikan yang dihasilkan lebih besar dari alpha $(\alpha)$, yakni $0,346>0,05$. Hal ini berarti menunjukkan bahwa keputusan yang diambil adalah menerima $\mathrm{H} 0$ dan menolak H1, berarti secara parsial Sanksi Perpajakan tidak berpengaruh secara signifikan terhadap Kemampuan Membayar Pajak

\section{PENUTUP}

\section{Kesimpulan}

Penelitian ini bertujuan untuk mengetahui pengaruh variabel Efektivitas Sistem Perpajakan, Kesadaran Membayar Pajak, dan Sanksi Perpajakan Terhadap Kemampuan Membayar Pajak. Berdasarkan hasil penelitian seperti yang telah diuraikan pada bab sebelumnya, dapat ditarik kesimpulan secara parsial yaitu :

1. Efektivitas Sistem Perpajakan berpengaruh signifikan terhadap Kemampuan Membayar Pajak. Dapat dilihat dari t hitung lebih besar jika dibandingkan $\mathrm{t}$ table $(4,966>1,984)$ serta nilai signifikansi Efektivitas 
Sistem Perpajakan terhadap Kemampuan Membayar Pajak lebih kecil dari nilai signifikansi $(0,000<0,05)$ sehingga menerima $\mathrm{H} 1$ dan menolak $\mathrm{H} 0$.

2. Kesadaran Membayar Pajak tidak berpengaruh terhadap Kemampuan Membayar Pajak. Dapat dilihat dari t hitung lebih kecil jika dibandingkan $\mathrm{t}$ table $(1,676<1,984)$ serta nilai signifikansi Ambiguitas Peran terhadap Kinerja Auditor lebih besar dari nilai signifikansi $(0,097>0,05)$ sehingga menerima H0 dan menolak H1.

3. Sanksi Perpajakan berpengaruh signifikan terhadap Kemampuan Membayar Pajak. Dapat dilihat dari t hitung lebih kecil jika dibandingkan $\mathrm{t}$ table $(0,947<1,984)$ serta nilai signifikansi Sanksi Perpajakan Terhadap Kemampuan Membayar Pajak lebih besar dari nilai signifikansi (0,346> 0,05) sehingga menerima $\mathrm{H} 0$ dan menolak $\mathrm{H} 1$.

\section{Saran}

Berdasarkan penjelasan hasil penelitian dan pembahasan serta simpulan dalam penelitian ini maka saran dalam penelitian ini adalah:

1. Penelitian ini menggunakan kuesioner sehingga hasil yang diperoleh berdasarkan persepsi jawaban responden. Hal ini dapat menjadi masalah jika terjadi perbedaan persepsi antara pertanyaan yang ditafsirkan oleh responden dengan pertanyaan yang diharapkan oleh peneliti. Untuk penelitian selanjutnya diharapkan dapat menggunakan metode yang berbeda seperti wawancara langsung dengan responden sehingga peneliti dapat menjelaskan secara langsung maksud dari pertanyaan dan memastikan bahwa responden dapat memahami pertanyaan yang diajukan sehingg hasil yang diperoleh tidak bias dan sesuai dengan apa yang dimaksud oleh peneliti.

2. Penelitian ini hanya menggunakan 3 variabel saja maka untuk penelitian selanjutnya dapat menambah variabel-variabel diluar penelitian ini yang kemungkinan memiliki pengaruh terhadap kemampuan membayar pajak agar dapat memperoleh hasil maksimal.

3. Diharapkan pada penelitian selanjutnya dapat menambah populasi yang lebih luas dan menambah variabel lain.

\section{DAFTAR PUSTAKA}

Buku :

Erly Suandy, 2011. Hukum Pajak Edisi 5. Jakarta : Salemba Empat.

Ghozali. 2012 Aplikasi Analisis Multivariate IBM SPSS 22. Semarang: Universitas Diponegoro.

Mardiasmo. 2014, Perpajakan. Edisi Revisi. Yogyakarta: Andi.

Muttaqin, Zainal. 2013. Tax Amnnesty di Indonesia. Bandung: Refika Aditama.

Jurnal Ilmiah Akuntansi dan Ekonomi Volume. 1 Nomor. 5 Februari 2020

Hal. 81 
Ridwan, \& Engkos, K. A. (2007). Cara Menggunakan dan Memaknai Analisis Jalur (Path Analysis). Cetakan Pertama. Bandung: Alphabeta.

Robbins, S. P., \& Judge, T. A. (2015). Perilaku Organisasi (Organizational Behavior). Jakarta: Salemba Empat.

Soewadji, J. (2012). Pengantar Metodologi Penelitian. Jakarta: Mitra Wacana Media.

Santoso, Singgih. 2011. SPSS Statistic Parametric . Jakarta: PT Alex Media Computindo Gramedia.

Sugiyono. 2015. Metode Penelitian Kuantitatif Kualitatif dan R\&D. Bandung: Alfabeta.

Ramage, C. S. (1971), Monsoon Meteorology, Academic press inc., International

Geophysics Series.

Jurnal :

Fahluzy dan Agustina. 2014.Penagruh Persepsi dan efektifitas sistem perpajakan, kepercayaan, tarif pajak, kemanfaatan NPWP terhadap kemampuan membayar pajak. Jurnal Akuntansi Perpajakan. Edisi 2014.

Nurlis dan Kamil. 2015. Pengaruh kesadaran membayar pajak, sanksi perpajakan, administrasi perpajakan, moderen, pengetahuan korupsi dan tax amnesty terhadap kemampuan membayar pajak. Jurnal Pajak.

Iva. 2012. Pengaruh Sunset Police, tax amnesty, dan sanksi perpajakan terhadap kemampuan membayar pajak. Jurnal Akuntansi.

Popi Fauziati. 2015. Pengaruh Efektifitas Sistem Perpajakan dan pelayanan fiskus terhadap kemauan untuk membayar pajak dengan kesadaran membayar pajak sebagai variabel intervening. Jurnal Akuntabilitas. Univ. Bung Hatta.

Diyanto, Volta. 2014. Pengaruh Pengetahuan dan pemahaman, efektifitas sistem perpajakan, dan pelayanan fiskus terhadap kemampuan membayar pajak dengan kesadaran membayar pajak sebagai variabel intervening. Jurnal pajak. Univ. Riau.

Widyati dan Nurlis. 2010. Faktor- faktor yang mempengaruhi untuk membayar pajak wajib pajak orang pribadi yang melakukan pekerjaan bebas. Studi kasus pada KPP Pratama Gambir III.

Yulianawati, Nila. 2011. Faktor-faktor yang mempengaruhi kemauan membayar pajak The factos that Influence the wilingness to pay the tax. Jurnal dinamika keuangan dan perbankan. 